Stever, Director of the National Science Foundation, which has a significant stake in the enterprise) to make a study of the effects.

NACOA also believes that the fragmentation in the federal government's management of marine affairs has important implications for resource management and exploitation. In particular, it is not helping development of a strategy for exploiting oil and gas deposits on the outer continental shelf, and there is confusion over who has the chief responsibility for controlling the development of deep water ports.

But the committee does see a way out of the tangled situation in marine affairs -creation of a cabinet-level Department of Natural Resources which would bring together all the programmes that have a bearing on ocean and atmospheric affairs and place them in a single division. President Nixon has proposed the setting up of such a department-.. the Department of Energy and Natural Resources---but the fate of the proposal. which is now being considered in Congress, is anybody's guess. With the help of the growing concern over the energy crisis, however, it is generally considered that legislation setting up an umbrella department will emerge from Congress in some shape or form next year.

\section{OIL SHALE}

\section{Rootin' in the Rockies}

by our Washington Correspondent IN the next decade or so, a remote area of the Rocky Mountains is likely to undergo a dramatic transformation. At present a ranching and hunting area, it will probably become more and more industrialized and its population could almost double by 1985 . The reason is that it is sitting on perhaps the richest oil shale field in the world, and the rapidly escalating cost of petroleum is making its exploitation increasingly attractive to the oil industry. Surprisingly, however, proposals to open up the oil shale fields to commercial development have so far sparked little opposition from environmentalists, and they have certainly failed to achieve the notoriety of ventures such as the transAlaska pipeline.

The shale is concentrated in a formation centred in the region where Colorado, Utah and Wyoming meet, and it is reckoned to contain some 1,800 (US) billion barrels of crude oil. Of that total, the National Petroleum Council reckons that about 130 (US) billion barrels are contained in deposits that can now be exploited economically, while the Department of Interior puts the figure at about 600 (US) billion. By contrast, proven reserves of oil from other sources in the United States are reckoned to be about 425 (US) billion barrels.

Oil shale consists of organic deposits called kerogen, locked into rock. To extract oil from the shale requires a process involving mining the shale, crushing it up and heating it in a closed retort; since it is such a costly process compared with drilling for conventional petroleum, the price of petroleum has to be right before exploitation becomes economically attractive. Nevertheless, it is widely expected that sizable oil shale exploitation will take place over the next decade or so, and the Department of Interior is hoping to lease six tracts of land two in each of Colorado, Utah and Wyoming for prototype commercial production. Last week, the department published its final analysis of the likely environmental effects of the prototype programme, and it also took a speculative look at the environmental damage likely to result from possible full-scale exploitation of the field.

A massive, six volume set of documents running to some 3,200 pages, the environmental impact statement clearly shows that even the prototype programme will significantly alter the characteristics of the area, and that full commercial production will essentially change it from a rural to a semi-industrial region. The prototype programme is designed to allow the oil industry to develop the technology for full commercial exploitation of the shale field, and it will probably result in production of up to 250,000 barrels of shale oil a day. The department reckons, however, that as much as 1 million barrels of shale oil a day could be produced from the region by 1985 if the prototype programme proves the feasibility and acceptability of commercial production.

As for environmental damage, the environmental impact statement shows that although the mining and processing operations will have to conform to present federal and state environmental laws, there will be irreversible effects. The mining operations themselves will cause some damage, particularly in one tract in Colorado which will be surface mined--the others will be underground operations-but disposal of the crushed rock after removal of the shale oil will present a more difficult problem. Some of the rock will be replaced in the mine shafts, but the excess will be used as landfill. There will also be adverse effects on air quality, resulting from dust and, more important, from sulphur dioxide emissions from the retorts.

But one of the chief problems is likely to arise from the use of water in the extraction and processing operations. The region is arid, and already water is not in particularly plentiful supply. Thus, the impact statement suggests that ultimately the availability of water could limit commercial exploit- ation to about 1 million barrels of shale oil a day.

In the long run, however, the chief irreversible effect on the environment is likely to stem from the fact that oil shale production will attract many people to the area, resulting in a population boom which will result in nearly 115,000 people living in the region by 1985 , assuming full-scale commercial production is under way by then. In 1970 , the seven counties that comprise the oil shale region had a total population of only 119,000. As the impact statement points out, "that oil shale basins are characterized by their wildlife resources, essentially undeveloped natural resource condition, and limited human activity.... Thus the remote and primitive character of parts of (the region) will be lost".

\section{TENURE \\ Getfing Locked In}

Tenure has been coming under increasing fire in the United States in the past few years, particularly in colleges and universities faced with rapidly escalating costs and a preponderance of red ink on the balance sheet. Administrators in such institutions nave complained that the growing proportion of teaching staff with tenure-appointments for life -is gradually locking higher education into a set structure because it is making it difficult for institutions to respond to changing enrolment patterns by phasing out some courses and introducing or expanding others. Their complaints have now been put into perspective by a survey carried out by the American Council on Education*. According to responses from more than 42,000 college and university teachers, the percentage of faculty members holding tenured positions has increased from 46.7 to $64.7 \%$ in the past four years. One result of the trend is that some institutions have been forced to dismiss faculty members rather than give them tenure.

Alongside the increase in tenured faculty, the survey has brought to light the fact that the average age of academic teaching staff has increased $(58.7 \%$ are over the age of 40 , compared with $54.4 \%$ four years ago) and the proportion of faculty members holding associate or full professorships has also gone up (from 42.3 to $50.7 \%$. Women and minority groups have also increased their representation on university and college teaching staffs, but hardly by leaps and bounds--the survey shows that their numbers grew from 19.1 to $20 \%$, and from 2.2 to $2.9 \%$, respectively.

*Teaching Faculty in Academe: 1972-73, $\$ 3.00$. Available from ACE, 1 Dupont Circle, Washington DC 20036. 